10-2009

\title{
Malthus' Essay on Population and the American Debate Over Slavery
}

Dennis Hodgson

Fairfield University, hodgson@fairfield.edu

Follow this and additional works at: https://digitalcommons.fairfield.edu/sociologyandanthropologyfacultypubs

Copyright 2009 by Cambridge University Press. Original published version can be found at DOI: $10.1017 /$ S0010417509990120

\section{Peer Reviewed}

\section{Repository Citation}

Hodgson, Dennis, "Malthus' Essay on Population and the American Debate Over Slavery" (2009).

Sociology \& Anthropology Faculty Publications. 2.

https://digitalcommons.fairfield.edu/sociologyandanthropology-facultypubs/2

\section{Published Citation}

Hodgson, Dennis. 2009. Malthus' Essay on Population and the American Debate Over Slavery. Comparative Studies in Society and History 51(4):162-163.

This item has been accepted for inclusion in DigitalCommons@Fairfield by an authorized administrator of DigitalCommons@Fairfield. It is brought to you by DigitalCommons@Fairfield with permission from the rightsholder(s) and is protected by copyright and/or related rights. You are free to use this item in any way that is permitted by the copyright and related rights legislation that applies to your use. For other uses, you need to obtain permission from the rights-holder(s) directly, unless additional rights are indicated by a Creative Commons license in the record and/or on the work itself. For more information, please contact digitalcommons@fairfield.edu. 


\title{
Malthus' Essay on Population and the American Debate over Slavery
}

\author{
DENNIS HODGSON
}

\author{
Sociology and Anthropology, Fairfield University
}

Malthus published his Essay on Population in 1798 and for the next century, as the new discipline of political economy incorporated his thought into its central tenets, population theorizing took place largely within a Malthusian framework. A stark simplicity marks his argument, especially as presented in the succinct first edition of the essay. He presents the reader with two self-evident natural laws: "that food is necessary to the existence of man," and "that the passion between the sexes is necessary and will remain nearly in its present state" (1798: 11). He then observes, "The power of population is indefinitely greater than the power in the earth to produce subsistence for man" (13), and contends that population, when unchecked, increases in a "geometrical ratio" while subsistence in only an "arithmetical ratio" (14). In this first edition, Malthus had the particular ideological goal of proving that "the advocates of equality and of the perfectibility of man" had an unattainable dream. Mr. Godwin could imagine a British Isle where all are equal, live in "airy" farmhouses, share "the necessary labours of agriculture" (182), and divide its fruits "according to their wants," Malthus observed, but such a regime places no barrier to early marriage and large families. He calculated that in a hundred years the Isle's seven million people "would be one hundred and twelve millions, and the food only sufficient for thirty-five millions, leaving seventy-seven millions unprovided for" (23-24). Since "no possible form of society could prevent the almost constant action of misery upon a great part of mankind" (36), constructing a society of equals only ensures a society in which all will be poor. Any attempt to improve the conditions of the impoverished by granting them access to subsistence, such as the poor laws then in effect in England, simply works "in some measure to create the poor which

Acknowledgments: I want to thank the three anonymous CSSH reviewers for their many insightful comments, especially for suggesting that I add African American voices to this debate. My thanks also go to David Akin at CSSH for a very supportive editorial process. The article is much improved as a result of their help. 
they maintain" since they permit the poor man to "marry with little or no prospect of being able to support a family in independence" (83).

Malthus considered the United States to be the exception proving his rule that the availability of subsistence was holding human numbers in check (ibid.: 104-5). With just five million people and an immense frontier, Americans could marry early and have large families, and even with the population doubling every twenty-five years, the nation faced no immediate resource constraints. Although temporarily relieved of "Malthusian" worries, Americans nonetheless found Malthus' Essay insightful. America did not have Europe's sharp social inequalities, at least among its white population, nor were its leaders anxious about revolutionary ideologies provoking social upheaval. In antebellum America the great divide lay between the sections, and the issue of expansion, not scarcity, was the focus of debate. Although Malthus did not directly address this issue in his Essay, Americans found that it contained real lessons about how a sparsely settled land should be peopled.

Thomas Jefferson, for example, when thanking Jean-Baptiste Say in 1804 for sending his two-volume Traité d'Economie Politique, related, "These found me engaged in giving the leisure moments I rarely find, to the perusal of Malthus' work on population, a work of sound logic, in which some of the opinions of Adam Smith, as well as of the economists, are ably examined" (1804a: 1-3). ${ }^{1}$ Using Malthus' contrasting ratios, Jefferson proceeded to distinguish Old and New World demographic conditions: "There, for instance, the quantity of food is fixed, or increasing in a slow and only arithmetical ratio, and the proportion is limited by the same ratio. Supernumerary births consequently add only to your mortality. Here the immense extent of uncultivated and fertile lands enables every one who will labor, to marry young, and to raise a family of any size. Our food, then, may increase geometrically with our laborers, and our births, however multiplied, become effective." This fortunate situation posed a new question for Jefferson: did the immensity of land mean that America should be a nation of farmers? He mused that for Europe "the best distribution of labor is supposed to be that which places the manufacturing hands alongside the agricultural; so that the one part shall feed both, and the other part furnish both with clothes and other comforts. Would that be best here?" Already a participant in an ongoing debate, he argued that while "egoism and first appearances say yes" to such a mix, "the moral and physical preference of the agricultural, over the manufacturing, man" made a nation of farmers his choice. He closed by commenting that if Say did not address his questions it

1 In his 29 January 1804 letter to Joseph Priestley, Jefferson offers this positive assessment of Malthus: "Have you seen the new work of Malthus on population? It is one of the ablest I have ever seen. Although his main object is to delineate the effects of redundancy of population, and to test the poor laws of England, and other palliations for that evil, several important questions in political economy, allied to his subject incidentally, are treated with a masterly hand" (1804b). 
was because "you wrote for Europe; while I shall have asked them because I think for America."2 Obviously Jefferson found Malthus' reflections on population valuable, but not necessarily for what they had to say about the possibility of social equality or the efficacy of poor laws.

SECTIONAL USES OF MALTHUS' ESSAY

Malthus' Essay on Population made its appearance just as sectional conflicts were increasing in importance in America. Should manufacturing be fostered with tariffs, or agriculture with free trade? Should the frontier be tilled by freemen on farms or by slaves on plantations? My contention is that the sectional debate over slavery so greatly influenced Americans' assessment of Malthus' Essay that there was no general "American" appraisal of Malthus, but there was a "northern" and a "southern" appraisal. Advocates from each section emphasized the importance of quite different components of Malthus' population theory, and then proceeded to use a sectional "Malthusianism" to further their goals.

Consider the first question: What kind of economy should the nation foster, manufacturing or agricultural? Malthus' theory of population quickly became incorporated into the core of classical economics, especially as elaborated by David Ricardo. Ricardo used Malthus' population theory to explain why wages would tend to remain at subsistence levels. With respect to cultivators, as their numbers increase they have to move to less fertile land; their productivity declines while their landlords' ability to raise rents increases. With respect to industrial workers, a higher than subsistence wage simply allows them to marry earlier and have more children, which eventually increases the supply of workers and depresses wages back to subsistence levels. Advocates of southern interests embraced the pessimistic Malthusianism of Ricardo and of Malthus' first edition of the Essay when "vice" and "misery" were the only mechanisms containing population growth. They contended that this bleak picture revealed the true nature of all "free-labor" systems. The growth of manufacturing and trade advocated by the North ultimately could not produce a prosperous republic, but only a mass of "free" workers living at the edge of subsistence and a few wealthy landlords and capitalists. They presented the slave system, with plantation workers behaving according to the dictates of their masters, not their passions, as a humane alternative to the bleak "freelabor" system; one that might avoid the ruinous consequences of redundant reproduction. Although in later editions of his Essay Malthus elaborated additional, less dismal mechanisms of population control, "moral restraint" being chief among them, southern proslavery advocates had little use for them.

Had Malthus lived through the 1840 s and 1850 s, he very likely would have disavowed the bleak "Malthusian" forecasts found in many southern works on

\footnotetext{
2 The English translation of Say's treatise, appearing in 1821, actually proved to be very influential, "dominating the United States textbook market until after 1837" (Conkin 1980: 28).
} 
the future of free labor societies. As early as 1806 he took offense when advocates of slavery used his Essay to further their cause. Parliament was then debating abolishing the slave trade and opponents to its abolition were using his "Principle of Population" to contend that the slave trade was no evil but was actually helping to augment the number of Africans in the world. Malthus responded by adding an appendix to the third edition of his Essay (1806: 556-59) in which he explicitly called for ending that trade. In the body of his Essay Malthus argued that since Africa's population was already being held in check by the availability of subsistence, exporting slaves simply produced more "spaces" in Africa that were quickly filled by greater numbers of Africans surviving. Opponents to ending the slave trade took note of this point and argued that every slave exported to the West Indies, then, was actually a net addition to worldwide African numbers. In this sense the slave trade was an essential benefit to Africans. In his new appendix Malthus sought to refute this reasoning by arguing that the slave population in the West Indies was constantly in need of new additions to keep from shrinking in size. This inability to reproduce meant that "the immediate checks to population must operate with excessive and unusual force" on this population and this "incontrovertibly proves that the condition of the slaves in the West Indies, taken altogether, is most wretched" (556-57). Malthus gave his new appendix to William Wilberforce to use in the debates in order "to rescue my character from the imputations of being a friend of the slave trade" (Drescher 2002: 43).

While in Britain opponents to ending the slave trade were basing their case on Malthus' contention that the availability of subsistence determines population size and density, in the United States northern opponents to the spread of slavery were using that same contention to argue that slavery was necessarily displacing whites with blacks. Daniel Raymond, for instance, in his pamphlet The Missouri Question (1819) virtually replicated passages from Malthus' Essay to assert that every slave was "displacing" a white person. He began (ibid.: 20) by repeating Malthus' assertion that populations have a tendency to increase "in a geometrical ratio" and that "where the means of subsistence are abundant, are capable of doubling their numbers every fifteen years." While Malthus (1798: 23-24) calculated the results of a hundred years of geometric increase of the British Isles' population, Raymond calculated the results of a hundred years of geometric increase of the 1800 U.S. black population: "In other words, if one million will increase to two millions in twenty years, then upon the same principle that two will, provided the means of subsistence are equally abundant, increase to four in forty years, that four to eight in eighty years, that eight to sixteen millions in a century, and so on to thirty two millions in twenty years more [ $\left.\operatorname{sic}^{3}\right]^{\prime \prime}(1819: 19)$.

\footnotetext{
3 Raymond actually makes a mathematical mistake in this "geometrical ratio." He is doubling the population every twenty years, and yet at year forty, when the population is four million, he
} 
He did not use this calculation to question the efficacy of poor laws, but rather to attack the legitimacy of the southern vision of the Republic's future. Should the frontier be tilled by freemen on farms or by slaves on plantations? For Raymond the "science of population" (ibid.: 12) proved that each plantation worked by slaves supplanted numerous white homesteads and each individual slave displaced a white person: "If all the product of the earth be consumed by slaves, a white population cannot subsist; and whatever portion of the product of the earth is consumed by slaves, in the same proportion will the increase in the white population be limited or restrained. In other words, every slave in the world, especially in our country occupies the place of a free man" (ibid.: 20). This race-based "displacement" argument became a powerful northern rhetorical weapon, used to great effect in Congressional debates and public discussions.

I contend that the existence of these two different Malthusian strategies employed by sectional advocates explains why commentators have arrived at very different assessments of the importance of "Malthusianism" in the American debate over slavery. J. J. Spengler, focusing on the pessimistic Malthusianism that became embedded in classical economics, argued (1935; 1936) that southerners constructed a powerful proslavery argument "built upon Malthusian principles" that "only a slave economy was immune to the many social ills allegedly inherent in a free capitalistic economy" (1935: 170). Eugene and Elizabeth Genovese (1984) were not as convinced as Spengler that pessimistic Malthusianism was central to proslavery thinking. Eugene Genovese, however, did note how Thomas Dew and a number of other southern figures used pessimistic Malthusian ideas to advance the proslavery cause (1986; 1992). C. Van Woodward (1971, esp. ch. 3, "Southern Slaves in the World of Thomas Malthus") and Robert Fogel (1989, esp. ch. 5, "The Population Question") examined American racial demographic trends and charted American responses to Malthus' displacement model. They found that the model played a significant role in sectional debates over slavery. James R. Gibson, Jr. noted that Americans began the nineteenth century with varied responses to Malthus' Essay but increasingly rejected pessimistic Malthusianism as they came to embrace the goal of an industrial society (1989). Edmond Cocks (1967) and George Cady (1931) noted strains of both pessimistic Malthusianism and the rejection of pessimistic Malthusianism in antebellum American thought, but did not trace them to sectional origins; Cocks drew connections to political party affiliation and Cady to affiliation with particular schools of economic thought.

I argue that political economy argument played a key role in policy debates during the antebellum period, and that both southern and northern sectional advocates consciously used Malthus' population ideas in an instrumental

forgets that it should double to eight million by year sixty, not year eighty. So, one million blacks would reach thirty-two million in a century, not in 120 years. 
manner. Those debating the place of slavery in America made extensive use of scripture, biology, and law in arguing their case, but both sides also appealed to "the laws of population" expounded by Malthus to advance their positions and actively engaged each other's "Malthusianism" when debating the place of slavery in American society. As early as 1809, a version of Malthus' third edition of the Essay was published in the United States. In antebellum journals in both the North and South numerous articles touched on Malthus' "Principle of Population" and the slavery question. Twenty-two such articles appeared in North American Review between 1815, when it began publication, and 1860, and nine appeared in The United States Review between 1837 and 1858. In the South, Debow's Review published twenty such articles between 1846 and 1860, and ten appeared in the Southern Literary Messenger between 1834 and 1860.

The extensive use of Malthusian arguments first appeared in the debates that developed over how Missouri should enter the Union, as slave state or free. In preparation for that debate two northerners, Daniel Raymond and Robert Walsh, published separate pamphlets that employed extensive Malthusian "displacement" analyses of U.S. racial population statistics to argue that slaves displaced whites wherever slavery was permitted (Raymond 1819: 8-37; Walsh 1819: 93-103). In the actual Congressional debates on the Missouri question congressmen on both sides regularly referred to Malthus by name (Hemphill 1820: col. 1132; Tucker 1820: col. 1532; Barbour 1820: col. 2078). Tucker, then a representative from Virginia who was soon to become a professor of political economy at the University of Virginia, even presented a brief history of the evolution of population theory to his congressional colleagues: "These principles of population, now so familiar to all, were first distinctly stated, so far as my information extends, by Sir James Steuart. They are also noticed by Dr. Franklin, and seem to have been an original suggestion of his own good sense and sagacity. But their influence in producing human misery and vice, and in circumscribing the efficacy of governments, were never fully developed, before the appearance of Mr. Malthus' Essay on Population, which I cannot but consider as a work of great ability" (Tucker 1820: col. 1532).

The Benjamin Franklin work Tucker mentions is his 1751 essay, "Observations Concerning the Increase of Mankind." In this "influential precursor of Malthus' Essay on Population" (Hodgson 1991: 639) Franklin argued that the number of all living things, man included, were held in check "by their crowding and interfering with each other's means of subsistence” (1755: 9). He also commented on the negligible impact that slavery had on Africa's population, noting that "natural generation" quickly filled any "vacancy" caused by the slave trade: "Who can now find the vacancies ... made in Guinea, by one hundred years' exportation of slaves, that has blacken'd half America?" (ibid.: 8-9). Malthus discovered Franklin's Observations while writing the greatly expanded second edition of his Essay (1803: iv), and incorporated both Franklin's "crowding" and "slavery" observations into that edition (pp. 2, 104). 
Readers of the American edition of Malthus' Essay, therefore, also would have been well aware of Franklin's contributions to the "laws of population"; in fact, both men were often referred to by those using population arguments when debating the slavery issue.

Soon after his Missouri pamphlet appeared, Raymond published the first American text on political economy (Ely et al. 1919: 751): Thoughts on Political Economy (1820). An expanded edition appeared in 1823, titled Elements of Political Economy. Both contained Malthusian "displacement" analyses of U.S. racial population statistics (1820: 438-51; 1823, vol. 2: 361-80). During the 1820 s political economy also became established in southern universities, with Thomas Cooper first teaching the subject at South Carolina College in 1820, George Tucker at the University of Virginia in 1825, and Thomas Dew at the College of William and Mary in 1827 (Carlander and Bownlee 2006: 392). As will be seen, all were to weave a defense of slavery into their teaching of the subject that employed pessimistic Malthusian predictions about the ultimate fate of free labor societies.

That very different policy conclusions were deduced from a consideration of the same Essay illustrates how a preexisting policy position can influence the way in which one "reads" a work. It hints at the primal character that population debates assumed during an era when policies concerning the peopling of America were being directly formulated, as well as the depth of the fissure that divided the sections. This particular episode in U.S. policy history is especially interesting since each side claimed to be disciples of Malthus, and therefore had to respond to the "Malthusian" arguments of its opponents. One can trace how Malthusian argument generated Malthusian counterargument, and how sectional advocates often found themselves assuming quite provocative, perhaps uncomfortable positions as a result.

The best way to examine this episode is to focus on the particular "Malthusian" argument of each side and on the counterarguments their sectional opponents generated in response. This approach entails some jumping back and forth in time, but the interesting use to which Malthus' ideas on population were put can best be highlighted in this way.

\section{THE SOUTH'S USE OF PESSIMISTIC MALTHUSIANISM}

Southern scholars were attracted to Malthusianism, especially as expounded by Ricardo, because it allowed them to project a bleak future for the "free-labor" system: since the supply of workers will inevitably increase faster than the demand for their services, the mass of mankind is destined to live at the edge of subsistence. ${ }^{4}$ Against such a foil, the slave system could appear as a

\footnotetext{
4 In 1858 a three-part series entitled "The Problem of Free Society" appeared in the Southern Literary Messenger, with "R.E.C." listed as the author. It contains the most elaborate Malthusian argument against the free-labor system and for the slave system, although many pieces of this
} 
humane alternative. As early as 1819, southern proslavery advocates were unfavorably contrasting the conditions of the "2,000,000 of white slaves" in British factories with the conditions of the two million black slaves on southern plantations ("Parvus Homo" 1819).

In the slave system the capitalist actually "owned" labor, and ownership made the interests of the two groups cooperative, not competitive. Unlike in the freelabor system, competition could not force the slave owner to give his workers a less than subsistence wage since this would entail destroying his own capital: "A planter lives by the labor of his slaves: he must therefore keep them in a condition fit to labor" (Cooper 1835: 191). Furthermore, the slave owner could control his charges' reproduction to prevent overpopulation: "The Southern slave-holder is able to support all his slaves in comfort, because he keeps no more than can be profitably employed; but if you force him to keep ten times as many, will not master and servant come to starvation? It is this very selfprotecting power against over-population existing in slave countries, which is wanting in free society. This is our safe-guard. .." ("R.E.C." 1858: 12-13).

How could slave masters control the number of their slaves? They could manipulate the sex ratio. Seybert argued that prior to 1808 , when it still was legal to import slaves, slave masters purchased few females "because a refined calculation had taught the masters, that it cost less to buy grown up slaves than it did to raise them" (1818: 53). Dew noted the sudden increased prolificacy of Louisiana slaves that occurred after the slave trade was abolished and the price of slaves increased (1832: 55). He contended that if slave masters were so motivated they could double the number of their slaves in fifteen years by encouraging marriage and exempting females from labor (ibid.: 54).

For southern scholars, Malthus had laid bare the fundamental flaw of the free-labor system, and allowed them to posit that widespread prosperity would only be possible within the controlled community of a slave system. The pessimistic Malthusianism embraced by proslavery advocates, however, did contain a prediction that should have made them less than sanguine about slavery's future: as population size and density increased in the free-labor North, wages would approach subsistence levels and the cost of "free" workers would fall below that of slaves (O'Brien 1992: 568). If their criticism of the North's free-labor system was correct, their slave system was doomed. In Thomas Dew's apocalyptic vision of a teeming America, for example, there was no room for slavery:

But the time must come when the powerfully elastic spring of our rapidly increasing numbers shall fill up our wide spread territory with a dense population-when the great safety valve of the west will be closed against us - when millions shall be

argument can be found earlier. Spengler $(1936,386)$ believes that the "R.E.C." is Raleigh Edward Colston. 
crowded into our manufactories and commercial cities - then will come the great and fearful pressure upon the engine - then will the line of demarkation stand most palpably drawn between the rich and the poor, the capitalist and the laborer - then will thousands, yea, millions arise, whose hard lot it may be to labor from morn till eve through a long life, without the cheering hope of passing from that toilsome condition in which the first years of their manhood found them... (1836: 277).

Although they might paint horrific visions of the future of a free-labor America, antebellum proslavery advocates did not expect pessimistic Malthusianism to convince northerners of the need for the North to adopt a slave-based economy. Eighteenth-century events already had foreclosed that possibility. The process of emancipating slaves began in the New England states soon after the Revolution and had moved southward as the century ended. The Northwest Ordinance, banning the further introduction of slavery north and west of the Ohio River had been passed in 1787. Before the century's end slavery largely had been isolated as the peculiar institution of the South. Antebellum proslavery advocates had a more limited goal for their pessimistic Malthusianism: to argue against the need to legislate an end to slavery or to legislate the containment of slavery. They used Malthus" "law of population" to prove that population growth was all that was needed to bring about the gradual and peaceful end to slavery. Henry Clay, in the 1819-1820 debate over whether Missouri should be admitted to the union as a slave state or a free state, presented just such an argument, as reported by Congressman Sergeant:

In this long view of remote and distant consequences, the gentleman from Kentucky (Mr. Clay) thinks he sees how slavery, when thus spread, is at last to find its end. It is to be brought about by the combined operation of the laws which regulate the price of labor and the laws which govern population. When the country shall be filled with inhabitants, and the price of labor shall have reached a minimum (a comparative minimum I suppose is meant) free labor will be found cheaper than slave labor. Slaves will then be without employment, and, of course, without the means of comfortable subsistence, which will reduce their numbers, and finally extirpate them (1820: col. 1211).

George Tucker advanced the identical argument in his speech on the Missouri question: "As soon as our population has overspread the whole habitable parts of our territory, and brought our waste lands into cultivation, human labor will begin to decline in value... In the same proportion that the price of labor diminishes, must the value of slaves decline, until at length the cost of bringing up a slave will be more than he is worth. When that period arrives, the community will not, and cannot, impose on itself the burden of supporting slaves" (1820: cols. 1534-35). In both cases, the predictions of slavery's future demise were used to help preserve its present existence; pessimistic Malthusianism was used to "prove" that no legislation was needed to end slavery. Patience and population growth, abolitionists were told, would bring slavery to a gradual and peaceful end. Tucker repeated this argument until his death in 1861 (1837: 48; 1843: 115-18; 1860: 88-89). 
In the Missouri debate Tucker did add an interesting proviso to the "peaceful" end to slavery. For that to happen, he argued, slaves had to be allowed access to western lands as the nation expanded. If slaves were restricted to the current slaveholding states then in a century there would be twenty-four million slaves in these states and "the blacks would be to the whites nearly in the proportion of three to one" (1820: col. 1534). The nation's population would be 160 million, but the entire west would be exclusively white. In the slaveholding states the whites who remained would find "the African race constantly pressing on them" and a "struggle between the two races" would ensue. This struggle could end in one of two ways: Whites could "finally abandon the country, and leave the blacks undisputed masters of the soil"; or, more likely, violence could break out that would "end in a war of extermination." But if "the slaves be allowed to spread themselves equally with the white population west of the Mississippi," a peaceful end to slavery would happen: "Then they must always continue, as they now are, inferior in number to the whites; and, when the period arrives, as it certainly must, when the self-interest of individuals will burst the bonds of the slave, emancipation will then consist with the tranquility and safety of the State." Tucker believed that regardless of how the Missouri question was settled, "the line of local division" of that future United States would be "not as at present, between the North and the South, but between the Western and Atlantic States." He told legislators from the "Atlantic States" that if they succeed in "the confinement of the black population to the east of the Mississippi" then in the future "the strength and influence of the Atlantic States will be greatly impaired" when competing with the western states since, "A State will possess more wealth, and strength, and weight in the Legislature, when inhabited by freemen than by slaves" (ibid.: col. 1535).

Interestingly, Tucker was one of the most notable nineteenth-century American students of population. He was the first to construct child/women ratios from census data and to uncover evidence of an early decline in fertility. This finding led him to question whether the U.S. population would actually increase "geometrically" until checked by the availability of subsistence (1843: iii; 1860: 80-82). He argued that "prudence and pride" seemed capable of checking population growth well before subsistence levels were reached. Although this finding had clear implications for his theory about slavery's inevitable end, he never thoroughly considered them in his writings.

Southerners used pessimistic Malthusianism both to cloak slavery in moral superiority, and paradoxically, by predicting its death, to shield it from an abolitionist onslaught. Few northern intellectuals, however, were inclined to embrace pessimistic Malthusianism even though it could be seen as predicting slavery's demise. They considered it to be a slight-of-hand defense of slavery, a southern delaying tactic. And a number argued that if white labor ever did become less expensive than slave labor the likelihood that slavery would end "naturally" and "peacefully" was slight. A densely settled future America 
filled with impoverished whites and newly emancipated slaves seemed an environment primed for violence. This was Representative Sergeant's retort to the vision of slavery's end that Henry Clay presented during the Missouri debates. Sergeant played along with Clay's scenario and then asked: "what number of slaves we shall have (with the previous encouragement proposed to be given to them) when this severe law shall begin to operate?" Since "the diminished price of labor, and the reduced means of subsistence, are, according to this theory, first to operate upon the freemen, and then upon the slaves, and upon both by producing a considerable degree of misery," Sergeant imaged that neither group would just wait until "slow destruction arrives" and argued that what Clay really was predicting was not a peaceful end to slavery but a future race war: "When want and misery begin to press upon them, instinct will teach them how to seek relief, and deadly violence will be its agent." He concluded by asking if it would not be better to contain slavery now to "see the experiment tried upon a small scale than a large one" (1820: cols. 1211-12).

Pessimistic Malthusianism with its prophecy of a densely settled America filled with impoverished industrial workers did question the wisdom of the northern blueprint for America. It required a direct rebuttal. Early in the century Mathew Carey, the northern pamphleteer and writer on economic matters, noted that the soil of Northeastern states was relatively "sterile" and that "the comparative density of their population render manufacturing establishments indispensably necessary to them" (1815: 373). If pessimistic Malthusianism was correct, these states had a bleak future and should already be the new nation's center of poverty. The opposite, however, seemed true to northerners, and many disavowed pessimistic Malthusianism on empirical grounds that had a sectional underpinning. Alexander Everett constructed a comprehensive treatment of population, New Ideas on Population (1823), which turned Malthus' pessimistic theory on its head. All empirical evidence showed, according to Everett, that both population growth and increasing density were directly related with rising prosperity, not poverty: "The increase of population has a natural tendency to produce a comparative abundance of the means of subsistence at the time and place of its occurrence" (1827: 138). Henry Carey, Mathew's famous son, expressed his anti-Malthusianism in similar terms: "With the increase of population and the extension of cultivation over the inferior soils, there is a constant increase in the return to labour, enabling men rapidly to improve their physical and moral condition. .." (1840: 53-64). He later elaborated a theory that rising density would "naturally" bring about a decline in fertility and thereby prevent overpopulation (1860: 301).

As the century progressed, the apparent economic success of the North gave little reason to northerners to adopt pessimistic Malthusianism. The unequal progress of the two sections was so evident in 1850 census figures that southern scholars felt compelled to explain it (Wish 1960: 25). They routinely attributed 
it to unfair tariff laws: "The rise of New York, and the proportional fall of Charleston, date from the enactment of the laws favourable to northern capital, invested in manufactures and other industries!" (Southern Quarterly Review 1851: 535). Some produced valiant, if strained demonstrations that wealth was actually greater in the South. Fisher, for instance, counted slaves as property, added their value to southern wealth totals, and calculated wealth figures on a "per free white" basis (1849). James D. B. DeBow, superintendent of the 1850 census and editor of DeBow's Review, contrasted the economic progress of the North with its moral degradation: "Does the increase of its aggregate wealth and population denote a more general diffusion of individual plenty; more happiness; a higher refinement, and a superior religious and moral tone of public sentiment? No man can doubt that in these things the North has retrograded" (1851: 361-62).

DeBow's focus on distributional issues and morality became the most common southern rejoinder to northern aggregate material progress, and such rejoinders became increasingly needed after non-slave-owning southern whites began to use such sectional growth disparities to question the value of slavery (Helper 1857). Although the free-labor system of the North appeared to be out-producing the South's slave system, its abundance was only being experienced by the rich: "It is, however, preposterous to find the moderns inveighing against the servitude of either an inferior or congeneous race, when the whole tendency of their doctrines, their practices, and the social organization of free-labor communities, is to make the mass of the laborers and even of the educated classes, subject to capital, circumstances, and machinery; to render them slaves of the ring and of the lamp; and to degrade and brutalize in the name and by the arts of commerce, manufactures and financial speculation" (Holmes 1855: 571).

Malthusian population theory was used to "prove" why such maldistribution was inevitable: "If population - that is labor-is, by a fixed principle, always held at the utmost point of repletion at which it can sustain itself, with a tendency still to press on in a geometrical ratio of increase, which tendency is only checked by a want of the means of subsistence, is it not obvious that if you furnish the means of subsistence you remove the only obstacle to its almost infinite production? ... Subsistence is all that labor receives out of its own products, because, with subsistence, any amount of labor may be commanded ("W" 1843: 740).

As tensions between the two sections increased during the $1850 \mathrm{~s}$, southern depictions of northern circumstances grew more unrestrained. George Fitzhugh combined Malthusian theory and class warfare rhetoric to illuminate free-labor conditions: "Crime and pauperism have increased. Riots, trades unions, strikes for higher wages, discontent breaking out into revolution, are things of daily occurrence... . Self-interest makes the employer and free laborer enemies. The one prefers to pay low wages, the other needs high wages. War, constant war, 
is the result, in which the operative perishes, but is not vanquished; he is hydraheaded, and when he dies two take his place. But numbers diminish his strength" $(1854 ; 1857 ; 1850: 3,7)$. By contrast, the South, with no population problem, was peaceful and free of poverty: "At the slaveholding South all is peace, quiet, plenty and contentment. .. . Population increases slowly, wealth rapidly. In the tide water region of eastern Virginia, as far as our experience extends, the crops have doubled in fifteen years, whilst the population has been almost stationary.... We have enough for the present and no Malthusian specters frightening us for the future. Wealth is more equally distributed than at the North, where a few millionaires own most of the property of the country" (Fitzhugh 1850: 12).

With America splitting apart, one's view of the world was ever more determined by place. Whether one saw prosperity or poverty, progress or regression, depended on locale. Southerners enthusiastically adopted pessimistic Malthusianism because it legitimized their particular vision of the world. They could predict poverty for an increasingly prosperous North and present slavery as a more equitable and humane institution than the free-labor system, and have these visions appear as consequences of natural laws, not simple reflections of sectional prejudice. Given its utility, eschewing pessimistic Malthusianism would have been difficult for a southern scholar. The North's increasing material progress did lead southerners to change the focus of their pessimistic Malthusianism. They emphasized inequality, not absolute poverty, and identified the war between capital and labor not as a future problem but a present reality. By the 1850 s, their critiques of the North's free-labor system were so harsh that immediate succession from the union increasingly presented itself as a sensible policy. That such radical critiques of industrial capitalism were associated with advocacy of slavery, conversely, did little to enhance their standing among northerners.

THE NORTH'S USE OF THE MALTHUSIAN DISPLACEMENT MODEL

Malthusian pessimism gave southerners a powerful ideological weapon with which to fight sectional policy conflicts. Yet when those battles were fought with data rather than ideas, Malthus' analytical framework became a problem for southerners. Malthus' axiom that the availability of subsistence ultimately determines human population size and density implies that a specific number of "places" exists for humans in a given territory. Each person filling a place in a sense "displaces" all others. In the analysis of subpopulations, this framework assumes that the presence of one group displaces other groups, and that one group's growth diminishes the potential growth of other groups. That the large number of slaves in the South displaced whites was often observed, and the reason frequently given for the paucity of immigrants in the South (Rush 1806: 208; M. Carey 1830: 218-22).

During the antebellum period, analyses of racial population-growth statistics became a central element in important policy debates: whether new states 
should enter the union as slave or free; whether American blacks should be expelled to colonies in Africa or elsewhere; and whether manumission should be legally required. In each of these debates a central issue became the displacement of whites by blacks or blacks by whites, and demographic statistics and "the laws of population" were brought into play. Interestingly, it was northerners, many of whom were ideologically opposed to pessimistic Malthusianism, who commonly employed the Malthusian displacement model in their studies of racial population dynamics, and they always arrived at conclusions inimical to southern interests. Daniel Raymond, in his 1819 pamphlet The Missouri Question addressed each of these three issues in displacement terms: westward expansion and racial displacement; colonization as an international displacement device; and manumission as a way to transmute a rapidly growing slave population into a slowly growing free black population. His early treatment of these issues often served as the spur that incited rejoinders, so we will begin our examination of each of these issues with the position that he staked out in that essay.

As we have seen, Daniel Raymond framed the issue of admitting Missouri into the union as a slave state in starkly demographic terms: "The questions for politicians to decide," he asserted, is "whether that policy is best which promotes the increase of a free white population, by restraining the increase of a slave population, or that which promotes the increase of a slave population, by restraining the increase of a free white population" (1819: 8-9). ${ }^{5} \mathrm{He}$ explicitly employed the Malthusian displacement model to argue that slavery not be permitted in Missouri: "Whatever portion of the product of the earth be consumed by slaves, in the same portion will the means of subsistence be taken from a white population, and in the same proportion will the increase of the white population be limited or restrained" (ibid.: 20). ${ }^{6}$ He noted that allowing a territorial expansion of slavery also would increase the demand for slaves and stimulate their production in the Old South, thereby greatly enlarging America's slave population and displacing more whites. He estimated that planters, with a ready export market for slaves in western states, would double the number of their slaves every fifteen years (ibid.: 32). Ultimately,

\footnotetext{
5 Raymond was not the first to frame the issue this way. Earlier Patrick Henry had asked, "Our country will be peopled. The question is, shall it be with Europeans or with Africans?" (in Jordan 1968: 544).

${ }^{6}$ Ideologically, Raymond was a staunch anti-Malthusian. In his text, Thoughts on Political Economy, he considered Malthus' Essay to be an essentially partisan document that favored the rich: "It is very convenient and very palatable for those who have all the property, to preach up the inutility of making provision for those who have none; and with them a theory of population, or a system of political economy, which establishes such a doctrine would be likely to be very popular, and by taking half views of a subject, or one branch of a system of political economy, as Mr. Malthus has done, there will be little difficulty in establishing almost any doctrine on almost any subject" (1820: 277). Frey traces a number of the positions that Raymond took with respect to inequality and property back to his puritan roots (2000).
} 
Raymond's displacement argument was informed by a profound racism that is encapsulated in his rhetorical question: "In a political, a moral, an intellectual, and a religious point of view, is not a white population better than a black one?" (ibid.: 25).

Proslavery advocates had a variety of responses to Raymond's Malthusian displacement argument. William Smith, senator from South Carolina, interpreted it as a despicable call for black genocide: "Raymond [has] the opinion, that it was better to condense these people within the limited space of the old States, and by that means reduce their numbers by a state of starvation and oppression. Heap cruelties on them to destroy the race" (1820: col. 268). So did William Scott, proslavery delegate from Missouri: "What, starve the negroes, pen them up in the swamps and morasses, confine them to Southern latitudes, to long scorching days of labor and fatigue, until the race becomes extinct, that the fair land of Missouri may be tenanted by that gentleman, his brothers and his sons" (1819: col. 1202). Henry Clay took a somewhat different tact. He argued, "The ratio of increase of slave population shows that its activity is now at the maximum; and, as this implies the existence of the most favorable circumstances, you cannot, by any change, accelerate the increase" (in Sergeant 1820: col. 1210). Since Malthusian limits had yet to be reached in the South, Clay reasoned that exporting slaves to Missouri would not increase the number of slaves, but only redistribute them. Sergeant responded to Clay with a Malthusian counterargument that changed the time frame from the present to the future: "Where you place a slave he occupies the ground that would maintain a freeman," whether in the present or the future, and when limits to subsistence are reached a present redistribution of slaves becomes a real future displacement of freemen (1820: col. 1211).

Raymond also used his analysis to argue against another possible displacement solution to America's "black problem" that was then gaining interest and that Clay favored: the "colonization" of American blacks to Africa or elsewhere (Raymond 1819: 7). This solution to America's racial problems had a long history. In 1787 Jefferson recommended freeing slaves and sending them to colonize "such place as the circumstances of the times should render most proper" (1787: 137-43). Madison, a fellow Virginian, voiced support for African colonization schemes a year later, and actively endorsed them until his death in 1836 (Jordan 1968: 552). Jefferson and James Monroe, who as Governor of Virginia put down a slave revolt in 1802, helped establish the American Colonization Society in 1817, which set about planning the establishment of the African colony of Liberia. According to its 1817 constitution, the Society's exclusive object was "to promote and execute a plan for colonizing (with their consent) the free people of colour residing in our country" (American Colonization Society 1827: 79). But the Society did have a larger goal: to use colonization to stop the growth of the America's entire black population. In its Second Annual Report, published in 1819, the Society was already calculating the 
funds that would be needed to "transport the whole annual increase of bond and free" blacks to Africa, a goal that, if met, would keep the country's black population at a constant size while its white population would continue to grow (American Colonization Society 1824: 101). ${ }^{7}$ Raymond in his essay on the Missouri question expressed doubt about the feasibility of this scheme to whiten America by estimating the annual natural increase of the nation's black population at about forty thousand, and noting that none of the colonization plans contemplated sending close to that number back to Africa each year (Raymond 1819). Nevertheless the colonization movement gained strength during the 1820s (Williamson 1986: 8) and Liberia was established in 1823.

The African colonization movement provoked much analysis of racial population dynamics, mainly because many of its advocates saw its goal as stopping black population growth. In both the North and South debate flared around the movement, but much of that debate was about the feasibility of attaining this goal rather than the goal itself. Henry Clay, Kentucky's most prominent politician, was a founder of the American Colonization Society and its president from 1836 to 1852 . Clay's vice-presidential address to the Society's annual meeting in 1827 was a study in racial population dynamics reminiscent of that of Raymond but with a very different policy conclusion. He began by emphasizing that the Society only was interested in transporting free blacks to Africa, and only those who wished to go. He said that if slave states wanted to colonize their emancipated slaves then they could do so on their own (1827: 338). Although never mentioned by Clay, this focus on just colonizing free blacks had the effect of dramatically reducing the projected cost of large-scale colonization and enhancing its feasibility: no purchase price of a slave had to be included in the cost of colonizing one black. Clay estimated the cost of transporting one free black to Africa and supporting him there for a year at the remarkably low figure of $\$ 20$; adding a $\$ 200$ to $\$ 300$ additional cost for the purchase of a slave would have made the economics of colonization, especially for a Society dependent on voluntary contributions, simply untenable. Clay began his analysis of population statistics by arguing that the overall population's past doubling time of twenty-five years had slowed somewhat to thirty-three years, that the slave population still was increasing at a rapid 3 percent annual rate, and that free blacks were noticeably "less prolific" than slaves because of "checks arising from vice and want" (ibid.: 340-41). Clay then calculated the annual emigration that in 1827 would be needed to reach the Society's goal of stopping the black population from continuing to grow, a figure that he estimated to be fifty-two thousand emigrants a year (ibid.: 279). Using his cost estimate of $\$ 20$ per emigrant, he calculated that

\footnotetext{
${ }^{7}$ I was unable to obtain the 1819 Second Annual Report of the Society, and here rely on extensive quotations from it that were published in the Seventh Annual Report (American Colonization Society 1824).
} 
black population growth could be stopped for an annual cost of $\$ 1,040,000$. Clay even invoked the "laws of population" to argue that this modest expenditure would have the added bonus of speeding up white population growth: "By the annual withdrawal of fifty-two thousand persons of colour, there would be annual space created for an equal number of the white race. The period, therefore, of the duplication of the whites, by the laws which govern population, would be accelerated" (ibid.: 342). Although Clay did note that the entire free black population of the United States was 233,530 in 1820 (ibid.: 276), he simply never acknowledged that all the country's free blacks would be "gone" after only five years of colonizing at the rate he was hoping to achieve. After that point colonization of slaves would be needed to keep America's black population from increasing.

There were northerners such as Mathew Carey who advocated colonization for virtually the same reasons as Clay. While admiring Raymond's work so much that he offered to fund a chair in political economy for him at the University of Maryland (Burke 1995: 59), Carey simply disagreed with him about the feasibility of the colonization scheme. He believed in the Society so much that he personally pledged to contribute $\$ 100$ a year for ten years to the colonization effort (Carey 1828: 272). Carey thought that a million dollars a year to keep the nation's black population at a constant two million in size was worth "tenfold the sum." Without colonization, he foresaw the "fearful prospect" that the black population would reach $10,669,236$ by 1870 (ibid.: 220). In contrast to the northerner Carey's optimism, George Tucker of Virginia, an early advocate of colonization, expressed the same doubts as Raymond about the feasibility of any colonization scheme attempting to move fifty thousand blacks from the United States to Africa each year (1820: col. 1535). He was more honest in his assessment of costs, estimating that each year $\$ 15$ million would be needed to purchase that many slaves, and another $\$ 5$ million to transport them to Africa.

The free black population itself had divided opinions about the colonization movement, although for very different reasons than white commentators. Some free blacks despaired of ever being treated fairly by white society and welcomed the opportunity for emigration. For instance, John Russwurm, one of the first African-Americans to get a college degree, initially fought against the colonization movement but then changed his mind and emigrated to Africa (Bay 2000: 26). Northern free black populations, however, generally opposed the movement from its beginnings. Free blacks in Philadelphia met at the Bethel Church in January of 1817, right after the founding of the American Colonization Society, and passed several anti-colonization resolutions which they sent to Joseph Hopkinson, their Congressman (Garrison 1832: 10). One objected to the aspersions about their character that were made at the founding session, "that they are a dangerous and useless part of the community." They also presented colonization as a "circuitous route" through which they would be returned to "perpetual bondage" and they resolved 
never to "separate ourselves voluntarily from the slave population of this country." In a second meeting in August 1817, they reacted to rumors that slaves might be forcibly returned to Africa, objecting that such colonization would only work to preserve slavery since "the Southern masters will colonize only those whom it may be dangerous to keep among them" while retaining the "tame and submissive" (ibid.: 12). In 1839 free blacks in New York City held a public demonstration against the colonization movement (Emancipator 1839), and in a scathing co-authored "letter" to officials of the American Colonization Society Samuel Cornish, the editor of The Colored American, and Theodore Wright, a pastor of a black Presbyterian Church, questioned their sincerity (Cornish and Wright 1840). The Society was telling free blacks that as emigrants they would have the noble task of converting and civilizing the indigenous African population. Why then, Cornish and Wright asked, did Society leaders such as its President Henry Clay call the free black population "the most corrupt, depraved, and abandoned" in the nation who "contaminated themselves" and "extend their vices to all around them"? How could Society leaders really think that such a population could succeed in "this magnificent enterprise for the exaltation and refinement ... of a benighted continent?" (ibid.: 15).

In reality, comparatively few blacks ever were actually relocated to Africa. In its first decade of colonizing the Society succeed in returning only 2,638 free blacks back to Africa (Kinshasa 1988: 30). There was one event in the 1830s, though, that did ignite interest in publicly funded large-scale colonization schemes. When Nat Turner led a band of rebel slaves and slaughtered at least fifty-five whites in Southampton, Virginia during the summer of 1831, fears of black insurrection swept the nation. On 4 July 1832, at Centre Church on the green in New Haven, Yale Professor Benjamin Silliman, co-founder of the Connecticut Colonization Society, gave an address predicting that without an invigorated colonization movement, in fifty years "an overwhelming population" of many millions of slaves "trained in physical hardship, and inured to privation" would mount an "insurrection of hundreds of thousands" that would massacre "virgins in their beauty and young men in their strength" in "promiscuous butchery" (1832: 171). In his vision of a protracted insurrection, the slaves "care not for their own thousands and tens of thousands slain; for they have still new myriads to replace them; while, on the other side, the prime and flower of youth and manhood fall beneath the hands of enraged savages; and the land is filled with pillage and conflagration, with violation and murder" (ibid.: 172). He called for a colonization movement funded with "public resources" that would transport one hundred thousand blacks to Africa each year (ibid.: 182). In 1832 the Maryland legislature actually responded to Nat Turner's rebellion by restricting the liberties of its free black population, creating a board to direct "the removal of coloured people," and appropriating \$20,000 to fund the colonization of Maryland free blacks willing to return to Africa, with the promise of an additional $\$ 200,000$ for that purpose over the next twenty years 
(Brugger 1996: 212-13). That same year the small farmers of western Virginia forced the Virginia legislature to consider a colonization scheme for dealing with Virginia's much larger slave population of 470,000 (Kaufman 1982: 85). The plan envisioned the state annually purchasing and shipping to African colonies a portion of the slave population equal to its yearly natural increase. This would keep Virginia's slave population constant in size while its white population would continue to increase and the state thereby would gradually become more white and the chance of insurrection would diminish.

During the Virginia legislative debate on the proposal Thomas Dew, the political economy professor at William and Mary College who later became its president, came to the slave owners' defense with a Malthusian analysis of black population growth again quite reminiscent of Raymond's, but again with a very different policy conclusion. Referring to "the principle of population" of "Dr. Malthus," he contended that the proposed plan would actually increase the slave population of Virginia. The state, by paying the market price for six thousand or more slaves each year, would increase the demand for slaves and stimulate their production: "Each master would do all in his power to encourage marriage among them - would allow the females almost entire exemption from labor, that they might the better breed and nurse" (1832: 53-54). ${ }^{8}$ Slave owners in other states would scheme to ship slaves into Virginia to avail themselves of this market. The white population, their taxes substantially increased to fund the plan, either would leave the state or find themselves less able to marry and start families (ibid.: 57). Dew argued that since colonization schemes would not work and since immediate manumission would devastate Virginia's economy, Virginia's only viable policy was an unequivocal endorsement of slavery: "Let us cherish this institution which has been built up by no sin of ours-let us cleave to it as the ark of our safety ... the day will come when the whole confederacy will regard it as the sheet anchor of our country's liberty" (1836: 279).

White ambivalence about slavery had engendered a plan to gradually displace blacks from Virginia that, ironically, Dew was able to convince legislators to abandon by emphasizing the selfishness of a slave-owning class who would breed slaves like cattle in pursuit of individual profit rather than limit black population growth in pursuit of racial hegemony (1832: 56). With all acceptable ways of shifting from a slave system to a free-labor system blocked, white southerners by the end of the 1830s largely did stop looking at slavery as a "problem" to be solved and began extolling it as a positive good. In the North the dream of a colonization end to America's "black problem" lived on. As late as 1857, Abraham Lincoln argued that it was in "our interest to transfer the African to his native clime, and we shall find a way to do it, however great the task may be" (1894:

\footnotetext{
${ }^{8}$ Since Virginia was already exporting six thousand slaves each year to other states, Dew thought that this was the minimum that the plan had to accommodate. He also estimated the annual cost of the plan, using $\$ 200$ as the average market value for a slave (1832: 149).
} 
338). Fredrickson contends that Lincoln's call to restrict slavery to its current territorial limits was motivated by a desire to create "economic and population pressures in the South that would compel the acceptance of gradual emancipation and colonization" (1988: 64).

There was an additional way of peacefully displacing America's blacks by whites that northern analysts of racial population statistics had identified: "manumission" of all slaves "as fast as possible" (Raymond 1819: 26). In his extensive analysis of the growth rates of whites, slaves, and free blacks in both slave states and free states Raymond found that the free black population increased more slowly than the white population in free states and more slowly than the slave population in slave states (ibid.: 8-9). This slow rate of increase of the free black population convinced him that blacks in freedom "are not so industrious, enterprising, and provident as the whites, and do not marry and raise so many children" (ibid.: 12). Manumission would transform a rapidly increasing slave population into a much more slowly increasing free black population (ibid.: 26) and, "The white population will increase in a greater, and the black, in a smaller ratio, until this eldest curse shall be eradicated." Raymond also attempted to sow seeds of discord among southern whites by claiming that the presence of slaves was currently lessening the fertility of landless whites: "A large portion of the white population in the southern states, are neither slave owners nor land owners.... not having property enough to raise families without their own manual labor, [they] prefer living single, (and as they call it respectably) to marrying and raising families, which they would be obliged to disgrace by manual labor" (1819: 20). With manumission Raymond believed that this situation would change.

With each decennial census a set of northern abolitionists continually updated Raymond's comparative analysis of racial population growth and argued with increasing urgency that, with colonization not working, manumission itself was the only way to have blacks "disappear" from the American population. For instance, Horace Bushnell, a distinguished New England theologian, analyzed 1820 and 1830 census statistics and told the "masters of the South" that only manumission could rid them of the growing security threat of their burgeoning black population: "Every year adds both to the danger and the difficulty, as it adds to the numbers of the slaves" (1839: 14). He calculated the very low population growth rates of the "colored populations" of Massachusetts, Rhode Island, Connecticut, New Jersey, and New York and concluded that blacks flourished in America only because of slavery: "At present they are kept from a decline in population only by the interest their masters have in them. Their law of population, now, is the same as that of neat cattle, and as the herd will dwindle when the herdsman withdraws his care, so will they" (ibid: 12, 13).

Arguing that the "African race" cannot "maintain the competition" with whites in freedom, he predicted that manumission would lead to their "premature 
extinction," following a path similar to that being experienced by the Native American. Bushnell later foresaw the end of the frontier, and forecast that an increasing white population in search of land would take over plantations and bring slavery to an end (1860). ${ }^{9}$ Indolence, improvidence, crime, and vice among the emancipated black population would lead to its early demise, an eventuality Bushnell considered progress: "Since we must all die, why should it grieve us, that a stock thousands of years behind, in the scale of culture, should die with fewer and still fewer children to succeed, till finally the whole succession remains in the more cultivated race?" (ibid.: 12-13).

Northerners more supportive of blacks still interpreted demographic statistics in ways similar to Bushnell. Jesse Chickering, a Massachusetts writer on statistical subjects, analyzed sixty years of census data and found the slave population of the South consistently increasing at a more rapid rate than the white population. He, too, foresaw a demographic Armageddon developing for southern whites: "The time must come when the slave population must outnumber and overpower the whites; and whenever a leader rises up among them, there is likely to be between these antagonistical elements, violence of the most awful kind" (1853: 137). He, too, found the natural increase of the "free colored population" to be stagnant: "There is a tendency in them, living in the midst of the whites and of the slaves, to degenerate, to dwindle away, and to become extinct as a race" (ibid.: 142-43). He attributed this not to racial inferiority, but to the severe discrimination that they experienced from whites in every region: "They seem to be doomed to perish in a state of freedom, falsely called, among a people whose feelings and whose prejudices loathe fellowship with them, and where the whole structure of society is set against their equal participation in the blessings of the land." Chickering still recommended that slaves be set free, but argued that every effort should be made "to aid in their colonization in Africa" so that the race could be saved (ibid.: 135). ${ }^{10}$

Free blacks, however, were never convinced that freedom would lead to extinction for the race. Fredrick Douglass questioned the accuracy of the census statistics that lay behind the argument. He noted that "colored people are, naturally enough, very suspicious of all white enquires into their numbers, and condition" and that "when a white man enters the house of a man of color, opens his book, takes out his pen, and proceeds in the usual authoritative tone to make enquires, the feeling generally is, 'that said white

\footnotetext{
9 Although Bushnell's 1860 analysis employs a Malthusian displacement framework, he explicitly states, "I do not believe in the principle, or supposed law of Mr. Malthus. .." (1860: 4). In this 1860 article he follows a demographic argument quite similar to that in George Weston's The Progress of Slavery in the United States (1857). Weston presented the relative population growth of free states and slave from 1790 to 1855 as being a war between two systems. He, too, felt that whites and the free-labor system would be the inevitable winners of this conflict.

${ }^{10}$ By this time approximately ten thousand American blacks had emigrated to Liberia (Chickering 1853: 142).
} 
man is after no good'; and he is not very likely to receive very truthful answer" (1851: col. E). Samuel Cornish and Theodore Wright thought that the possibility that "colored people would waste away, as the Indians have" after emancipation was very slight since blacks were already well integrated in "the social structure of the South" and have "certain offices" already assigned to them that they can perform "as well in a state of freedom as in a state of servitude." After a general emancipation "there will hardly be any derangement of the business of the country" so long as "the masters exercise ordinary prudence" and deal "fairly" with their emancipated slaves. If "paid for their work," blacks "will naturally continue in the discharge of offices to which they have been accustomed, and in which they have become expert," especially since it is unlikely that many "other offices for them to labor in for their support" will exist "for a long time" (1840: 15).

No southern legislature was so convinced by abolitionists' census analyses demonstrating a manumission way to whiten America that it legislated an end to slavery. Changing blacks from property to citizens promised too much political upheaval, especially in regions where slave owners already had succeeded in producing high ratios of slaves to whites. Even fears of violent slave revolts, endemic to regions with dense slave populations, did not make these regions receptive to the manumission argument. Owners of large numbers of slaves had a longstanding economic interest in having a high ratio of slaves to whites; it was, in reality, the traditional way to measure their wealth. Any plan that would "displace" their blacks with whites obviously threatened their economic interests. These slave owners, therefore, had an economic immunity to the racism that energized plans to manumit slaves in order to extirpate blacks. Non-slave-owning whites, both southern and northern, had no such immunity. They could oppose "inferior" blacks displacing whites in an overt way that owners of slaves never could.

From the beginning, Malthusian displacement analyses of differential population growth had the perverse effect of pushing southerners, especially slaveholding southerners, to adopt more unrestrained proslavery positions. Within the Malthusian displacement model slavery necessarily decreased the number and proportion of whites in a territory, and southerners, committed Malthusians, did not long dispute this. When northern analysts contended that enlarging slavery's territory would check white expansion, southerners came to accept this as fact and were forced to find in slavery a purpose more virtuous than propagating the white race. When northern analysts highlighted the low population growth rates of free blacks and announced manumission to be an effortless way of "whitening" America, southerners accepted this as fact and were forced to reject such a racial agenda. ${ }^{11}$ The high growth rate of the

\footnotetext{
11 With respect to slavery's influence on white immigration and white fertility, southerners also saw virtue where northerners saw only vice. For instance, Smith praised slavery for protecting the
} 
slave population that northerners decried, southerners came to praise. They hailed the rate as proof of slavery's beneficence, and declared that the institution was needed to protect the interests of a dependent race.

This assessment appears quite early, and can be seen in initial southern responses to Raymond's Malthusian displacement arguments. The more rapid increase of slaves than whites that, according to Smith, Raymond found to be "an evil of great magnitude," Smith contended was really "incontrovertible evidence that they are well fed, well clothed and supremely happy" (1820: col. 268). ${ }^{12}$ As the decades passed, these sentiments were voiced with increasing frequency. The slow rate of growth of the free black population that Bushnell heralded as evidence of the black's inability to compete with whites under freedom, Frederick Grimke contended should make "philanthropists ... cry out against the cruelty and injustice which would be done to the blacks by emancipating them." With whites no longer "maintaining a guardianship," the fate of blacks would be a sorrowful "extinction" (1848: 338). Van Evne equated "the cry of no more slave States" with the cry of "death to the negro" (1853: 10). Fitzhugh offered "the unexampled increase in the number of our slaves" as proof that slavery was "kindly, patriarchal, and protective" (1857: 633-34). Abolitionists, Grayson argued, could see free blacks "vanishing" from northern states and yet did not even "pretend to devise any scheme for escaping this monstrous result of the manumission they are recommending" (1860: 57).

Northerners used Malthusian displacement models of racial population dynamics to attack the racial fidelity of southern whites. Ironically, they thereby helped produce the "weirdly beautiful flower" of southern intellectual culture: the proslavery argument that presented the slave owner as savior of the black race (Williamson 1986: 15). Southerners, never repudiating their Malthusian principles, contrived to use the population trends that for northerners established southern racial perfidy to celebrate their racial altruism. Support for slavery became a mark of southern humanity, not southern whiteness.

\section{CONCLUSION}

When northerners finally forced emancipation on the South the sectionalism that had marked the American use of Malthusian population theory in debates over slavery quickly receded. With slavery no longer dividing the nation's whites,

South from the scourge of Irish and Chinese immigration (1856: 269-70). Dew found the lower fertility of southern whites a reflection not of their degeneracy, but of their "high degree of civilization"; unlike northerners, they refused to marry "unless there is a prospect of maintaining their families in the same style they have been accustomed to live in" (1832: 129).

12 Theodore Weld was one abolitionist who took such "population growth" proofs of the beneficence of slavery seriously. He considered and refuted a number of these arguments in great detail (1839). 
the consensus that most whites shared about black inferiority quickly extended to policy. Few voices of concern were raised when Joseph Kennedy, superintendent of the 1860 census, predicted that emancipated blacks were "doomed to comparatively rapid absorption or extinction" (1864: xi-xii). Some adopted Darwinian notions about the efficacy of competition and called on that new authority to suggest that no intervention was needed to forestall this eventuality. While Bushnell had seen the hand of "the Almighty Himself" in the replacement of the "inferior" by the "superior" (1860: 16), Julian Sturtevant saw "the law of competition" (1863: 606). But both God and science, seemingly, were in agreement that the progress of America required such a succession not be impeded.

The South's pessimistic Malthusianism and its radical critique of industrial capitalism largely disappeared from the American scene. The South had used it to deny legitimacy to the North's vision for America, but with the end of the slave system, few alternatives to industrial capitalism presented themselves. Although the proslavery critique of capitalism theoretically was closely aligned with that being made by Marx at the time, no former proslavery advocate made the leap from advocating the beneficence of slavery to advocating the need for communism.

The Malthusian displacement model used by northern advocates has not disappeared from the American scene, and has reemerged whenever new debates have arisen over the peopling of America. Later in the nineteenth century, for example, it reappeared in the debate over immigration restriction. In 1891 Francis Amasa Walker, superintendent of the 1870 and 1880 censuses and president of the Massachusetts Institute of Technology (1881-1896), called for closing the door to the swelling tide of Slavs, Jews, and Italians desiring entry into the United States. These "beaten men from beaten races," he contended, were not adding to the U.S. population but only displacing high-quality Anglo Saxon stock: "That if the foreigners had not come, the native element would long have filled the places the foreigners usurped, I entertain not a doubt." He believed that the "inferior" immigrant, willing to work for low wages, was the cause of low fertility among the native-born. The American "was unwilling himself to engage in the lowest kind of day labor with these new elements of the population; he was even more unwilling to bring sons and daughters into the world to enter into that competition" (1891: 640-42). This fear of the "inferior" displacing the "superior" fueled a racial nativism that eventually resulted in the discriminatory national origins quota acts of the $1920 \mathrm{~s} .{ }^{13}$ Whenever the peopling of the nation is openly contested, chauvinists can be counted on to use the displacement

\footnotetext{
13 For a treatment of Walker's thoughts on immigration and displacement see Hodgson (1992). Higham (1963: 142-43) thinks Walker exerted "a more telling intellectual influence" on the development of a racial nativism than either Henry Cabot Lodge or Nathaniel S. Shaler. Haller (1963: 54) identifies Walker's theory as "the first major impetus" in the generation of that nativism, since it "put into figures the fear that already gnawed at many American of native stock" and gave them substance.
} 
model to argue their cause. Today, race and ethnicity still divide the nation, but now America is no one's exclusive domain. Specialists analyze the nation's racial and ethnic composition, use sophisticated models to project future conditions, and present their findings in disinterested prose. Yet partisan eyes still often read between the lines and add to the commentary fears of displacement and hopes of hegemony. The questions that Malthus' Essay provoked among southerners and northerners in the antebellum period retain their relevance today.

REFERENCES

American Colonization Society. 1824. Seventh Annual Report of the American Society for Colonizing the Free People of Colour. Washington, D.C.: Davis and Force.

. 1827. Tenth Annual Report of the American Society for Colonizing the Free People of Colour. Washington, D.C.: Way \& Gideon.

Barbour, Philip. 1820 [1855]. 16th Congress, 1st Session, 9 Feb., cols. 2054-80. The Debates and Proceedings in the Congress of the United States. Washington, D.C.: Gales and Seaton.

Bay, Mia. 2000. The White Image in the Black Mind: African-American Ideas about White People, 1830-1925. New York: Oxford University Press.

Brugger, Robert J. 1996. Maryland, a Middle Temperament: 1634-1980. Baltimore: Johns Hopkins University Press.

Burke, Martin J. 1995. The Conundrum of Class: Public Discourse on the Social Order in America. Chicago: University of Chicago Press.

Bushnell, Horace. 1839. A Discourse on the Slavery Question. Hartford: Case, Tiffany and Co.

. 1860. The Census and Slavery. Hartford: Lucius E. Hunt.

Cady, George Johnson. 1931. The Early American Reaction to the Theory of Malthus. Journal of Political Economy 39, 5 (Oct.): 601-32.

Carey, Henry Charles. 1840. Principles of Political Economy, Part the Third. Philadelphia: Leas \& Blanchard.

1860. Principles of Social Science. Vol. III. Philadelphia: J. B. Lippincott.

Carey, Mathew. 1815. The Olive Branch: Or, Faults on Both Sides, Federal and Democratic. A Serious Appeal on the Necessity of Mutual Forgiveness and Harmony. 6th ed., enlarged. Philadelphia: M. Carey.

1828. Letter from Mathew Carey. The African Repository and Colonial Journal 4, 9 (Nov.): 270-72. . 1830. Miscellaneous Essays. Philadelphia: Carey and Hart.

Carlander, Jay R. and W. Elliot Brownlee. 2006. Antebellum Southern Political Economists and the Problem of Slavery. American Nineteenth Century History 7, 3 (Sept.): $389-416$.

Chickering, Jesse. 1853. The White, Free-Colored, and Slave Population of the United States. DeBow's Review 15 (Aug.): 129-43.

Clay, Henry. 1827. Address by Henry Clay. The African Repository and Colonial Journal 2, 11 (Jan.): 334-45.

Cocks, Edmond. 1967. The Malthusian Theory in Pre-Civil War America. Population Studies 20, 3: 343-63.

Conkin, Paul K. 1980. Prophets of Prosperity: America's First Political Economists. Bloomington: Indiana University Press.

Cooper, Thomas. 1835. Slavery. Southern Literary Journal 1, 3: 188-93. 
Cornish, Samuel and Theodore Wright. 1840. The Colonization Scheme Considered. Newark, N.J.: Aaron Guest.

DeBow, James Dunwoody Brownson. 1851. Population of the States, 1850 - Contrast of the North and the South. DeBow's Review 10 (Mar.): 361-62.

Dew, Thomas Roderick. 1832. Review of the Debate in the Virginia Legislature of 1831 and 1832. Richmond: T. W. White.

- 1836. An Address, on the Influence of the Federative Republican System of Government upon Literature and the Development of Character. Southern Literary Messenger 34 (Mar.): 261-82.

Douglass, Fredrick. 1851. The Free Colored Population. Frederick Douglass' Paper (Rochester, N.Y.), issue 27, 26 June.

Drescher, Seymour. 2002. The Mighty Experiment: Free Labor versus Slavery in British Emancipation. New York: Oxford University Press.

Ely, Richard Theodore, Thomas Sewall Adams, Max Otto Lorenz, and Allyn Abbott Young. 1919. Outlines of Economics. 3d ed. New York: Macmillan Company.

Emancipator. 1839. Great Anti-Colonization Meeting in New York. 17 Jan. (issue 38): 152, column F.

Everett, Alexander Hill. 1823. New Ideas on Population: With Remarks on the Theories of Malthus and Godwin. Boston: Oliver Everett (press of North American Review).

. 1827. Review of two books by J. R. M'Culloch: The Principles of Political Economy, with a Sketch of the Rise and Progress of the Science (1825); and An Essay on the Circumstances which Determine the Rate of Wages and the Conditions of the Laboring Class (1826). North American Review 25 (July): 112-53.

Fisher, Ellwood. 1849. The North and the South, Part 1; and Part 2. DeBow's Review 7 (Aug.): 134-45; and (Oct.)" 304-16.

Fitzhugh, George. 1850. Slavery Justified; by a Southerner. Fredericksburg, Va.: Recorder Printing Office.

. 1854. Sociology for the South, or the Failure of Free Society. Richmond: A. Morris.

. 1857. The War Upon Society_Socialism. DeBow's Review 22 (June): 633-36.

Fogel, Robert William. 1989. Without Consent or Contract: The Rise and Fall of American Slavery. New York: W. W. Norton \& Co.

Franklin, Benjamin. 1755. Observations Concerning the Increase of Mankind. Boston: S. Kneeland.

Fredrickson, George M. 1988. The Arrogance of Race: Historical Perspectives on Slavery, Racism, and Social Inequality. Middletown, Conn.: Wesleyan University Press.

Frey, Donald E. 2000. The Puritan Roots of Daniel Raymond's Economics. History of Political Economy 32, 3: 607-29.

Garrison, William Lloyd. 1832. Thoughts on African Colonization, Part II: Sentiments of the People of Color. Boston: Garrison and Knapp.

Genovese, Eugene D. 1986. Western Civilization through Slaveholding Eyes: The Social and Historical Thought of Thomas Roderick Dew. New Orleans: Graduate School of Tulane University.

- 1992. The Slaveholders' Dilemma: Freedom and Progress in Southern Conservative Thought, 1820-1860. Columbia: University of South Carolina Press.

Genovese, Eugene D. and Elizabeth Fox-Genovese. 1984. Slavery, Economic Development, and the Law: The Dilemma of the Southern Political Economists, 1800-1860. Washington and Lee Law Review 41, 1: 1-29. 
Gibson, James R. Jr. 1989. Americans versus Malthus: The Population Debate in the Early Republic, 1790-1840. New York: Garland Publishing.

Grayson, William J. 1860. The Dual Form of Labor. DeBow's Review 28, 1 (July): $48-66$.

Grimke, Frederick. 1848. The Nature and Tendency of Free Institutions. Cincinnati: H. W. Derby \& Co.

Haller, Mark H. 1963. Eugenics: Hereditarian Attitudes in American Social Thought. New Brunswick: Rutgers University Press.

Helper, Hinton Rowan. 1857. The Impending Crisis of the South: How to Meet It. New York: Burdick Brothers.

Hemphill, Joseph. 1820 [1855]. 16th Congress, 1st Session, Feb., cols. 1132-33. The Debates and Proceedings in the Congress of the United States. Washington, D.C.: Gales and Seaton.

Higham, John. 1963. Strangers in the Land. New York: Atheneum.

Hodgson, Dennis. 1991. Benjamin Franklin on Population: From Policy to Theory. Population and Development Review 17, 4 (Dec.): 639-61.

. 1992. Ideological Currents and the Interpretation of Demographic Trends: The Case of Francis Amasa Walker. Journal of the History of the Behavioral Sciences 28, 1 (Jan.): $28-44$.

Holmes, George Frederick. 1855. Ancient Slavery, Part 1. DeBow's Review 19, 5 (Nov.): 559-78.

Jefferson, Thomas. 1787 [1955]. Notes on the State of Virginia. William Peden, ed. Chapel Hill: University of North Carolina Press.

- 1804a [1903]. Letter to Jean-Baptiste Say, 1 Feb. In A. E. Bergh, ed., Writings of Jefferson. Vol. 11. Washington, D.C.: Jefferson Memorial Association, 1903.

. $1804 b$ [1903]. Letter to Joseph Priestley, 29 Jan. In A. E. Bergh, ed., Writings of Jefferson. Vol. 10. Washington, D.C.: Jefferson Memorial Association, 1903.

Jordan, Winthrop D. 1968. White over Black: American Attitudes toward the Negro 1550-1812. North Carolina: University of North Carolina Press.

Kaufman, Allen. 1982. Capitalism, Slavery, and Republican Values: Antebellum Political Economists, 1819-1848. Austin: University of Texas Press.

Kennedy, Joseph Camp Griffith. 1864. Population of the United States in 1860; Compiled from the Original Returns of the Eighth Census. Washington, D.C.: Government Printing Office.

Kinshasa, Kwando Mbiassi. 1988. Emigration vs. Assimilation: The Debate in the African American Press, 1827-1861. Jefferson, North Carolina: McFarland \& Co.

Lincoln, Abraham. 1894. Speech in Springfield, Illinois, 26 June 1857. In John G. Nicolay and John Hay, eds., Complete Works of Abraham Lincoln. Vol. 2. Washington, D.C.: Lincoln Memorial University, 315-39.

Malthus, Thomas Robert. 1798. An Essay on the Principle of Population, as It Affects the Future Improvement of Society, with Remarks on the Speculations of Mr. Godwin, M. Condorcet, and other Writers. London: J. Johnson.

-1803. An Essay on the Principle of Population. 2d ed. London: J. Johnson. J. Johnson.

. 1809. An Essay on the Principle of Population. Washington, D.C.: Roger Chew Weightman.

O'Brien, Michael. 1992. Conservative Thought in the Old South: A Review Article. Comparative Studies in Society and History 34, 3 (July): 566-76.

"Parvus Homo." 1819. Letter to the Editor. Daily National Intelligencer (Washington, D.C.) 27 May, Issue 1989: col. A. 
"R.E.C." 1858. The Problem of Free Society, I; II; and III. Southern Literary Messenger 26 (June): 401-18; 27 (July): 1-18; and 27 (Aug.): 81-94.

Raymond, Daniel. 1819. The Missouri Question. Baltimore: Schaeffer \& Maund, Printers.

- 1820. Thoughts on Political Economy. In Two Parts. Baltimore: Fielding Lucas, Jun'r.

E. J. Coale.

Rush, Benjamin. 1806. Essays: Literary, Moral and Philosophical. 2d ed. Philadelphia: Thomas and William Bradford.

Scott, William. 1819 [1854]. 15th Congress, 2d Session, 15 Feb., cols. 1195-203. The Debates and Proceedings in the Congress of the United States. Washington, D.C.: Gales and Seaton.

Sergeant, John. 1820 [1855]. 16th Congress, 1st Session, 9 Feb., cols. 1172-218. The Debates and Proceedings in the Congress of the United States. Washington, D.C.: Gales and Seaton.

Seybert, Adam. 1818. Statistical Annals of the United States of America. Philadelphia: Thomas Dobson and Son.

Silliman, Benjamin. 1832. Some of the Causes of National Anxiety. The African Repository and Colonial Journal 8, 6 (Aug.): 161-86.

Smith, William. 1820 [1855]. 16th Congress, 1st Session, 26 Jan., cols. 259-74. The Debates and Proceedings in the Congress of the United States. Washington, D.C.: Gales and Seaton.

Smith, William Andrew. 1856. Lectures on the Philosophy and Practice of Slavery. Nashville: Stevenson \& Evans.

Southern Quarterly Review [no author listed]. 1851. The Prospect Before Us. Southern Quarterly Review 3, 6: 533-41.

Spengler, Joseph John. 1935. Malthusianism and the Debate on Slavery. South Atlantic Quarterly 34, 2: 170-89.

. 1936. Population Theory in the Antebellum South. Journal of Southern History 2, 3: 360-89.

Sturtevant, Julian Monson. 1863. The Destiny of the African Race in the United States. Continental Monthly 3, 5: 600-10.

Tucker, George. 1820 [1855]. 16th Congress, 1st Session, Feb., cols. 1525-37. The Debates and Proceedings in the Congress of the United States. Washington, D.C.: Gales and Seaton.

- 1837. The Laws of Wages, Profits, and Rents, Investigated. Philadelphia: E. L. Carey \& A. Hart.

. 1843. Progress of the United States in Population and Wealth in Fifty Years as Exhibited by the Decennial Census. New York: Press of Hunt's Merchants' Magazine.

. 1860. Political Economy for the People. Philadelphia: C. Sherman \& Son.

Van Evne, Dr. 1853. Slavery Extension. DeBow's Review 15, 1 (July): 1-14.

"W" [from Westmoreland Co]. 1843. Slavery in the Southern States. Southern Literary Messenger 9, 12 (Dec.): 736-44.

Walker, Francis Amasa. 1891. Immigration and Degradation. Forum 11 (Aug.): 634-44.

Walsh, Robert ("A Philadelphian"). 1819. Free Remarks on the Spirit of the Federal Constitution, the Practice of the Federal Government, and the Obligations of the Union, Respecting the Exclusion of Slavery from the Territories and New States. Philadelphia: A. Finley.

Weld, Theodore Dwight. 1839. American Slavery as It Is: Testimony of a Thousand Witnesses. New York: American Anti-Slavery Society. 
Weston, George Melville. 1857. Progress of Slavery in the United States. Washington, D.C.: self-published.

Williamson, Joel. 1986. A Rage for Order: Black/White Relations in the American South since Emancipation. New York: Oxford University Press.

Wish, Harvey. 1960. Writings of George Fitzhugh and Hinton Rowan Helper on Slavery. New York: Capricorn Books (G. P. Putnam's Sons).

Woodward, C. Vann. 1971. American Counterpoint: Slavery and Racism in the North-South Dialogue. Boston: Little, Brown and Sons. 